\title{
Legal Protections for Armed Forces Personnel and Veterans serving in operations outside the United Kingdom Response to Public Consultation Questionnaire
}

\author{
Dr Stuart Wallace* \\ Dr Elizabeth Stubbins Bates ${ }^{\dagger}$ \\ Dr Noëlle Quénivet ${ }^{\ddagger}$
}

\section{Do you agree with this view?}

No.

\section{Explain why you think this.}

There are three problems with this view.

1. The proposed measures will not remove 'uncertainty ... about the prospect of re-investigation and prosecution' for service personnel because they are inconsistent with the UK's international legal obligations.

2. The proposals are unduly restrictive of the circumstances in which an investigation can be reopened.

3. It is counter-intuitive to create a statutory presumption against new investigations or prosecutions when no such presumption exists in domestic law.

First, the proposal that investigations which do not result in criminal charges are final (with no subsequent prosecution following unless there are 'compelling reasons') seeks to 'address the uncertainty faced by Armed Forces personnel'. However, it cannot remove (as the consultation document notes) obligations under the Geneva Conventions (and Additional Protocol I), ${ }^{1}$ the Rome Statute of the International Criminal Court (ICC) ${ }^{2}$ and (not noted in this part of the consultation document) several other legal instruments such as the European Convention on Human Rights

\footnotetext{
${ }^{*}$ Lecturer in Law, University of Leeds.

+ Junior Research Fellow, Merton College, University of Oxford; Research Fellow, Oxford Institute of Ethics, Law and Armed Conflict (ELAC), Early Career Fellow, Bonavero Institute of Human Rights, University of Oxford.

‡ Associate Professor in International Law, Bristol Law School, University of the West of England. The authors would like to thank Dr Natasa Mavronicola, Reader in Law, University of Birmingham and Dr Rebecca Sutton, Teaching Fellow, University of Edinburgh for their comments on earlier drafts.

${ }^{1}$ Geneva Convention for the Amelioration of the Condition of the Wounded and Sick in Armed Forces in the Field of 12 August 1949, 75 UNTS 31 (entered into force 21 October 1950) (GC I) art 50; Geneva Convention for the Amelioration of the Condition of Wounded, Sick and Shipwrecked Members of Armed Forces at Sea of 12 August 1949, 75 UNTS 85 (entered into force 21 October 1950) (GC II) art 51; Geneva Convention Relative to the Treatment of Prisoners of War of 12 August 1949, 75 UNTS 135 (entered into force 21 October 1950) (GC III) art 130; Geneva Convention Relative to the Protection of Civilian Persons in Time of War of 12 August 1949, 75 UNTS 287 (entered into force 21 October 1950) (GC IV) art 147; Protocol Additional to the Geneva Conventions of 12 August 1949, and Relating to the Protection of Victims of International Armed Conflicts, 8 June 1977, 1125 UNTS 3 (entered into force 7 December 1978) (API), arts 11 and 85.

${ }^{2}$ Rome Statute of the International Criminal Court, 2187 UNTS 3 (entered into force 1 July 2002).
} 
(ECHR), ${ }^{3}$ the Convention against Torture (CAT), ${ }^{4}$ the 1993 Chemical Weapons Convention, ${ }^{5}$ the 1954 Hague Convention on the Protection of Cultural Property ${ }^{6}$ and its 1999 Protocol, $^{7}$ the Optional Protocol to the Convention on the Rights of the Child on the Involvement of Children in Armed Conflict, ${ }^{8}$ and the 1979 Convention against the Taking of Hostages. ${ }^{9}$ The UK also has several obligations under customary international law, for example, Rule 158 of the Study on Customary International Humanitarian Law by the International Committee of the Red Cross (ICRC). This rule creates investigatory obligations for the UK:

States must investigate war crimes allegedly committed by their nationals or armed forces, or on their territory, and, if appropriate, prosecute the suspects. They must also investigate other war crimes over which they have jurisdiction and, if appropriate, prosecute the suspects. ${ }^{10}$

The ICRC Study provides numerous examples of this rule being accepted as applicable in both international and non-international armed conflicts as well as instances in which the UK has accepted this rule. ${ }^{11}$ The proposal cannot remove the UK's duty to comply with these obligations and the discharge of the obligations either expressly or impliedly demands a genuine or effective investigation. In certain circumstances, the obligations may even demand that the UK prosecute perpetrators. ${ }^{12}$ As a result, it cannot remove the 'uncertainty... about the prospect of re-investigation and prosecution' as these legal obligations will subsist. The proposal does not offer a 'legal protection' against prosecution because the UK's international legal obligations do not permit this. These are widely incorporated into domestic law too. ${ }^{13}$ The UK has also voluntarily committed itself to further investigatory obligations, for example, the UK drafted and universally supported the International

\footnotetext{
${ }^{3}$ Convention for the Protection of Human Rights and Fundamental Freedoms, ETS No 005 (entered into force 3 September 1953) (ECHR).

${ }^{4}$ Convention against Torture and Other Cruel, Inhuman or Degrading Treatment or Punishment, 1465 UNTS 85 (entered into force 26 June 1987) (CAT) art 8.

${ }^{5}$ Convention on the Prohibition of the Development, Production, Stockpiling and Use of Chemical Weapons and on their Destruction, 1975 UNTS 45 (entered into force 29 April 1997) art 7.

${ }^{6}$ Convention for the Protection of Cultural Property in the Event of Armed Conflict, 249 UNTS 215 (entered into force 7 August 1956) art 28.

${ }^{7}$ Second Protocol to the Hague Convention of 1954 for the Protection of Cultural Property in the Event of Armed Conflict, 2253 UNTS 172 (entered into force 9 March 2004) art 15.

${ }^{8}$ Optional Protocol to the Convention on the Rights of the Child on the Involvement of Children in Armed Conflict, 2173 UNTS 222 (entered into force 12 February 2002) art 6.

${ }^{9}$ International Convention against the Taking of Hostages, 1316 UNTS 205 (entered into force 3 June 1983), arts 8 and 12. This submission is however limited to the UK obligations under the Geneva Conventions, Additional Protocol I, the Rome Statute of the ICC and the ECHR.

10 See 'Rule 158. Prosecution of War Crimes' available at <https://ihl-databases.icrc.org/customary$\mathrm{ihl} /$ eng/docs/v1_rul_rule158\#targetText=Rule\%20158.,if\%20appropriate\%2C\%20prosecute\%20the\%20suspect s.> accessed 26 September 2019.

11 See 'Practice Relating to Rule 158. Prosecution of War Crimes' available at <https://ihldatabases.icrc.org/customary-ihl/eng/docs/v2_rul_rule158> accessed 26 September 2019 as well as JS 383 The Joint Service Manual of the Law of Armed Conflict, Chapter 16.

12 For example, the European Court of Human Rights has explained that the procedural requirement is implicit in Article 2 ECHR as 'a general legal prohibition of arbitrary killing by the agent of the State would be ineffective, in practice, if there existed no procedure for reviewing the lawfulness of the use of lethal force by State authorities' - McCann and Others v UK (App No 18984/91) 27 September 1995 at [161].

${ }^{13}$ See, for example, the Geneva Conventions Act 1957, the International Criminal Court Act 2001 and s.134 of the Criminal Justice Act 1988.
} 
Protocol on the Documentation and Investigation of Sexual Violence in Conflict as part of the Preventing Sexual Violence Initiative. ${ }^{14}$

The State cannot rely on provisions of its domestic law to justify failure to perform its obligations under a treaty. It is a well-known and recognised rule of customary international law, codified in Article 27 of the Vienna Convention on the Law of Treaties, that

A party may not invoke the provisions of its internal law as justification for its failure to perform a treaty. ${ }^{15}$

Second, the proposal assumes that previous investigations, which have not resulted in criminal charges, are themselves lawful and complete. While the proposal acknowledges that 'compelling reasons' may justify a re-opening of an investigation, it only seems to contemplate 'the emergence of new evidence' as justifying such an action. Other 'compelling reasons' should be recognised, such as an error of fact or law by the investigators, including the investigators' interpretation of applicable international law, as incorporated into domestic law, such as the Armed Forces Act 2006. Another 'compelling reason' would be an investigation which evidences inability or unwillingness to conduct a 'genuine investigation' under Article 17 of the Rome Statute of the ICC; and a further 'compelling reason' would be a failure to implement each of the criteria of an effective investigation into an alleged violation of Article 2 or 3 of the ECHR, as developed in the case law of the European Court of Human Rights, ${ }^{16}$ and domestic law. ${ }^{17}$ The State's capacity to avoid these obligations through derogation is limited as noted below. The range of 'compelling reason[s]' expands once these different obligations are taken into account, rendering the case for this proposal progressively weaker.

This presumption may lead the UK prematurely to write off investigations that it should continue. The Office of the Prosecutor (OTP) at the ICC is conducting a preliminary examination into the quality of the UK's investigations into alleged war crimes against British detainees in Iraq. ${ }^{18}$ It considers, inter alia, if any single or combined aspect of the UK's investigations into alleged war crimes against detainees in British military custody in Iraq might 'vitiate [the] genuineness' of the UK's investigation, having found 'reasonable grounds to believe that the UK armed forces committed war crimes 'against at least 61 victims in their custody ... in Iraq', including 'at least seven deaths as a result of abuse in custody'. ${ }^{19}$ While publicly available documents on the UK's investigations into this matter offer only a

\footnotetext{
${ }^{14}$ Second Edition of the International Protocol on the Documentation and Investigation of Sexual Violence in Conflict, March 2017 available at <https://assets.publishing.service.gov.uk/government/uploads/system/uploads/attachment_data/file/598335 /International_Protocol_2017_2nd_Edition.pdf> accessed 26 September 2019.

${ }^{15}$ Vienna Convention on the Law of Treaties, 1155 UNTS 331 (entered into force 27 January 1980).

${ }^{16}$ McCann (n 12) at [161]; Assenov and Others v Bulgaria (App No 24760/94) 28 October 1998 at [101]-[102]; Ribitsch v Austria (App No 18896/91) 4 December 1995 at [104] (on the reversed burden of proof in Art 3 investigations).

${ }^{17}$ Commissioner of Police of the Metropolis v DSD and another [2018] UKSC 11; MA, BB v Secretary of State for the Home Department (Equality and Human Rights Commission, intervening) [2019] EWHC 1523 (Admin).

${ }^{18}$ See Report of the International Criminal Court to the United Nations General Assembly, UN Doc A/74/324, 23 August 2019 available at <https://undocs.org/en/A/74/324> accessed 30 September 2019, at [50].

${ }^{19}$ ICC - Office of the Prosecutor, Report on Preliminary Examination Activities 2008, 5 December 2018, available at <https://www.icc-cpi.int/itemsDocuments/181205-rep-otp-PE-ENG.pdf> accessed 26 September 2019 at [195]-[196].
} 
thin dataset, it is not clear that there have been comprehensive investigations (potentially leading to prosecution) for war crimes relating to 'at least $61^{\prime}$ detainees. It might be that some of the investigations which have been closed require further scrutiny, instead of the introduction of a statutory presumption against prosecution and further investigation.

The UK does not have a good record of carrying out thorough investigations into alleged violations of international law during military operations. The European Court of Human Rights has found the UK in breach of its investigatory obligations in several cases on Northern Ireland. ${ }^{20}$ The judgments identified a range of problems with investigations into cases where it was alleged that British soldiers had unlawfully used force. The Court called into question the independence of the investigators, the promptness and effectiveness of the investigations and public scrutiny of the investigative process among other things.

The European Court of Human Rights identified a number of similar shortcomings in the UK's investigations into allegations of unlawful use of force in Iraq in the case of Al-Skeini $v U K .{ }^{21}$ In that case, lack of operational independence of investigators ${ }^{22}$ and shortcomings in the gathering of evidence (e.g. failure to identify Iraqi witnesses and persuade them to come forward) ${ }^{23}$ were identified as issues. The narrowness of the investigation, with its focus exclusively on criminal liability, was also criticised by the Court. ${ }^{24} \mathrm{An}$ investigation by RMP into the death of Nadheem Abdullah, who died from blows to his head inflicted by one or more British soldiers in Iraq on 11 May 2003, was considered to be inadequate and suffering serious omissions according to a British court-martial. ${ }^{25}$

The documents released by the Iraq Historic Allegations Team (IHAT) and the Service Police Legacy Investigations (SPLI) offer little information or indication that they carried out prompt, effective investigations, and the information given by them is too thin to permit public scrutiny. Arguably too, the next-of-kin cannot 'safeguard their legitimate interests', as required by the European Court of Human Rights, ${ }^{26}$ based on the very little information provided to them by IHAT and especially the SPLI. The UK's capacity to investigate the activities of its military personnel during its deployment in Iraq, for example, was extremely limited. ${ }^{27}$

Third, domestic law does not currently place a bar on new investigations in peacetime under any circumstances. It seems counter-intuitive that there is no statutory presumption against new investigations or prosecutions of "cold cases" that may have been investigated in peacetime with the

\footnotetext{
${ }^{20}$ Hugh Jordan v UK (App No 24746/94) 4 May 2001; McKerr v UK (App No 28883/95) 4 May 2001; Kelly v UK (App No 30054/96) 4 May 2001; Shanaghan v UK (App No 37715/97) 4 May 2001; Finucane v UK (App No 29178/95) 1 July 2003.

${ }^{21}$ Al-Skeini and Others v UK (App No 55721/07) 7 July 2011.

${ }^{22}$ Al-Skeini (n 21) at [171].

${ }^{23}$ Al-Skeini (n 21) at [170].

${ }^{24}$ Al-Skeini (n 21) at [174].

${ }^{25}$ Ferstman, Obel Hansen and Arajärvi, 'The UK Military in Iraq: Efforts and Prospect for Accountability for International Crimes Allegations? A Discussion Paper' available at <https://www1.essex.ac.uk/hrc/documents/THE_UK_MILITARY_IN_IRAQ_10ct2018.pdf> accessed 26 September 2019 at 13.

${ }^{26}$ McKerr (n 19) at [115] and [129]; Anguelova v Bulgaria (App No 38361/97) 13 September 2002 at [140].

27 Wallace, The Application of the European Convention on Human Rights to Military Operations (Cambridge University Press 2019) Chapter 4.
} 
full support of State authorities, detectives, pathologists, forensic investigators etc., but that the Ministry of Defence does seek to introduce a statutory presumption against prosecution where the alleged crime relates to actions carried out by the armed forces overseas, which may have been carried out under much more challenging circumstances with much more limited resources. ${ }^{28}$

It is noticeable that the consultation document refers to international humanitarian law and international criminal law, but not to the obligation to prosecute or extradite those suspected of involvement in the crime of torture, ${ }^{29}$ nor to the obligations to conduct an effective investigation into alleged unlawful killings or alleged torture, inhuman or degrading treatment or punishment under the ECHR. It is understood that the UK intends to derogate from the ECHR for future military operations. ${ }^{30}$ However this will not shield service personnel from the State's obligation to investigate, nor will it offer a 'legal protection' against uncertainty for several reasons:

a) Article 2 permits derogation only in respect of 'lawful acts of war', ${ }^{31}$ which for the purpose of this consultation response, we will interpret as being acts in full compliance with international humanitarian law and the international human rights law applicable to armed conflict. This implies a focus on the conduct of hostilities; and each investigation into an alleged breach of Article 2 would require a discussion of whether the State agent's act or omission was justified under the law on the conduct of hostilities. The State would not be able to derogate out of all its investigatory obligations under Article 2. The Court has clearly stated that a State's investigatory obligations continue to apply 'despite the prevalence of violent armed clashes [and] the high incidence of fatalities' ${ }^{32}$ and 'in difficult security conditions, including in a context of armed conflict'. ${ }^{33}$ Further, any derogation could not encompass deaths in custody as a result of unlawful killing, torture or inhuman or degrading treatment or punishment. Importantly, any deployment to a situation short of armed conflict would not engage the international humanitarian law on the conduct of hostilities. This could limit the State's capacity to derogate for 'lawful acts of war', assuming the European Court of Human Rights interprets this to mean international armed conflict. ${ }^{34}$

b) Article $3 \mathrm{ECHR}$ is non-derogable in its entirety, ${ }^{35}$ in its negative and positive obligations. This means that the obligation to conduct an effective investigation into alleged torture, inhuman and degrading treatment or punishment applies under Article 3 regardless of the government's stated intention to derogate from the ECHR in future military operations. As the proposed measures cover

\footnotetext{
${ }^{28}$ For a discussion of the challenges faced by armed forces in carrying out investigations overseas, see Quénivet, 'The Obligation to Investigate after a Potential Breach of Article 2 ECHR in an Extra-territorial Context: Mission Impossible for the Armed Forces?' (2019) 37(2) Netherlands Quarterly of Human Rights 119-138; Wallace (n 27) at $122-132$.

${ }^{29}$ CAT, art 8; see Criminal Justice Act 1988, s 134 and Armed Forces Act 2006, Schedule 2, para 12 (aq).

${ }^{30}$ Ministry of Defence, 'Government to Protect Armed Forces from Persistent Legal Claims in Future Overseas Operations' available at <https://www.gov.uk/government/news/government-to-protect-armed-forces-frompersistent-legal-claims-in-future-overseas-operations> accessed 12 September 2019.

${ }^{31} \mathrm{ECHR}$, Art 15(2).

${ }^{32}$ Ergi v Turkey (App No 23818/94) 28 July 1998 at [85]; Kaya v Turkey (App No 22729/93) 19 February 1998 at [91].

${ }^{33}$ Al-Skeini ( $\mathrm{n} 21$ ) at [164] as reiterated in Jaloud $v$ the Netherlands (App No 47708/08) 20 November 2014 at [186].

${ }^{34}$ Wallace (n 27) at 200-201.

${ }^{35} \mathrm{ECHR}$, art 15.
} 
'prosecution for any type of offence', this appears to include (in error) offences covered by the ECHR's non-derogable Articles.

c) Finally, the UK cannot retrospectively disapply the Convention to its military actions in Iraq and Afghanistan. We understand that these proposals would not apply to Northern Ireland, where ECHR obligations also cannot be disapplied retrospectively. The State's procedural obligations under the Convention, to carry out effective investigations into potential human rights violations in those theatres, would subsist regardless of whether this proposed law was passed.

Even if the State's obligations under the ECHR did not apply, its other obligations under international law, including the Geneva Conventions, Additional Protocol I, the CAT and customary international law, would still apply and require the State to investigate and prosecute service personnel [see further discussion below].

Q3. Do you agree with our proposals for who should be covered by this measure?

No comment.

Q4. Do you agree that the measure should not cover alleged offences committed against members of the UK Armed Forces, or against UK Crown Servants?

No comment.

\section{Q5. Please tell us why you think this.}

No comment.

Q6. Do you agree with our proposals for the circumstances in which the measure should apply?

No.

Q7. Please tell us why you think this, and in particular whether you have any alternative suggestions for the circumstances in which the measure should apply.

We do not believe the presumption should be enacted at all. Therefore, we do not agree with the proposed circumstances in which it might apply. However, there are problems with the construction of the circumstances at p.11 of the consultation document. First, there is flexibility and over-breadth in the phrasing: 'in the course of which members of the UK Armed Forces came under attack, or faced 
the threat of attack or violent resistance.' Does this descriptor apply to the whole 'military operation', thereby applying the proposed statutory presumption against prosecution to offences allegedly committed against detainees in British military custody (those hors de combat in international humanitarian law terms) when the colleagues of detention or intelligence officers had faced an 'attack or violent resistance' some days or weeks before? Does the descriptor instead apply only to alleged crimes, which might be connected to the use of force in a deployment in which they are currently facing an 'attack, threat of attack or violent resistance'? Might the descriptor include crimes committed against civilians or wounded insurgents, in an operation where troops have faced 'attack, the threat of attack or violent resistance' in the recent past? Further clarification is needed on these non-legal terms, which appear to be used to generate understandable empathy with soldiers facing such attacks. As the circumstances in which these proposals would apply would include 'combat operations, ... peacekeeping operations and operations for dealing with terrorism or civil unrest', it is important to note that international humanitarian law may not apply to all of these operations, and therefore the limited proposed derogation to Article 2 in respect of 'lawful acts of war' may not apply, and the rules of engagement on the use of force would also change.

Another issue relates to the planned distinction between alleged offences committed 'off duty' and 'on duty'. This fails to reflect applicable international law and presents practical difficulties. First, none of the aforementioned treaties provide for such a distinction to be made as they all refer to individuals rather than specific categories of individuals. Second, this distinction makes little sense as a member of the armed forces involved in an armed conflict, whether international or non-international, is a combatant at all times whether off or on duty under international humanitarian law. If they are attacked whilst off duty their act or omission in response to such an attack might still violate international humanitarian law and be considered a grave breach under the Geneva Conventions and API or a war crime. ${ }^{36}$ Yet, according to the proposal they would not be covered by the legislation. Various international criminal tribunals have convicted individuals of war crimes, crimes against humanity and genocide irrespective of their status. ${ }^{37}$ Third, whether members of the armed forces are on or off duty can sometimes be difficult to assess - is a peacekeeper who provides certain goods in exchange of sexual favours, i.e. sexually exploits a woman, on (whilst, for example, protecting a civilian convoy) or off duty (whilst, for example, 'visiting' a civilian camp in his free time)?

We have serious concerns about the planned retrospective effect of these proposals. Academic research and the UN Committee against Torture have both noted concerns as to the effectiveness of investigations into alleged torture and other ill-treatment in Iraq. ${ }^{38}$ The Committee against Torture specifically called on the UK government not to enact 'legislation that would grant amnesty or pardon

\footnotetext{
${ }^{36}$ It would be a war crime provided that a nexus between the act and/or omission and the conflict can be established. As explained in the Elements of Crimes of the International Criminal Court, '[w]ith respect to the last two elements listed for each crime: [...] (c) There is only a requirement for the awareness of the factual circumstances that established the existence of an armed conflict that is implicit in the terms "took place in the context of and was associated with".' Elements of Crimes, 2013 available at <https://www.icc-cpi.int/resourcelibrary/Documents/ElementsOfCrimesEng.pdf> accessed 26 September 2019 at 13.

${ }^{37}$ See e.g. Prosecutor v Akayesu, Judgment, ICTR-96-4-T, ICTR Ch I (2 September 1998).

${ }^{38}$ Stubbins Bates, 'Distorted Terminology: The UK's Closure of Investigations into Alleged Torture and Inhuman Treatment in Iraq' (2019) 68 International \& Comparative Law Quarterly 719; quoted in UN Committee against Torture, Concluding Observations on the UK's 6 ${ }^{\text {th }}$ Periodic Report, UN Doc CAT/C/GBR/CO/6, 7 June 2019 at [32].
} 
where torture is concerned'. ${ }^{39}$ The ICC OTP continues its preliminary examination (mentioned above) at this writing. Proposing that the statutory presumption against prosecution for historic offences committed by the armed forces overseas 'would not be limited to alleged offences committed after it was enacted' undermines the rule of law, and leaves these concerns unexamined. Retrospective effect poses concerns for the rule of law. So does the limited class of potential defendants (solely those from the armed forces, not civilians) which undermines equality before the law; and the territorial inconsistency, which fosters the idea that the UK accepts one standard of behaviour from its troops domestically, but another abroad. If the motivation of the proposal is to offer service personnel and ex-service personnel peace of mind that they will not be prosecuted for their activities long after events, it is unclear why this should be confined solely to their activities outside the UK.

\section{Q8. Do you agree that ten years is an appropriate qualifying time?}

No, the time limit of 10 years seems arbitrary and worse it could incentivise failures to investigate properly at the time events occur, followed by reliance on the exception the legislation would create. The need for this legislation is unclear, it is a solution in search of a problem. The levying of charges against service personnel for alleged unlawful activities is rare in practice and convictions are rarer still. We have concerns that the proposals will enshrine in law investigatory practices that need more, not less, scrutiny by Parliament and the courts.

Notwithstanding a huge number of allegations of unlawful conduct levied against British troops in Iraq, very few charges were brought against British soldiers. Prior to its closure in June 2017, the Iraq Historical Allegations Team received between $3,400^{40}$ and $3,600^{41}$ allegations that service personnel had engaged in unlawful killings and ill-treatment in Iraq. In total 'IHAT referred only two cases to the SPA for prosecution, but the SPA decided not to proceed with either of them. Two cases were referred to the Royal Air Force for further investigation but have been since closed, and one soldier was referred to his commanding officer for disciplinary action and was fined $£ 3,000^{\prime} .{ }^{42}$ The Service Police Legacy Investigations unit took over the remaining 1,280 allegations from IHAT and has closed 1,153 of them. As at 30 June 2019, there were 15 pending Full Investigations, and 12 Directed Lines of Enquiry, but no explanation as to the grounds on which earlier Full Investigations or Directed Lines of Enquiry had been discontinued. ${ }^{43}$ At this writing, there is no information publicly available to cover the actions of the SPLI since 30 June 2019.

An investigation into alleged unlawful conduct in Afghanistan, Operation Northmoor, has received 195 allegations of criminal conduct and 480 allegations of non- criminal conduct. Over $90 \%$ of these investigations have been discontinued and no cases have been referred to the Service Prosecuting

\footnotetext{
39 UN Committee against Torture ( $n$ 38) at [33].

40 Iraq Historic Allegations Team (IHAT) available at <https://www.gov.uk/government/groups/iraq-historicallegations-team-ihat> accessed 30 September 2019.

${ }^{41}$ ICC - Office of the Prosecutor (n 19) at [200].

${ }^{42}$ Ferstman, Obel Hansen and Arajärvi (n 25) at 16.

43 SPLI - Quarterly Update - 31 Mar 19 to 30 Jun 19 available at <https://assets.publishing.service.gov.uk/government/uploads/system/uploads/attachment_data/file/831723 /20190916-SPLI_QTR_RPT_31MAR19-30JUN19-FINAL.pdf> accessed 26 September 2019.
} 
Authority. ${ }^{44}$ An earlier investigation into criminal conduct in Afghanistan led to a number of courtmartial prosecutions, and some guilty pleas, ${ }^{45}$ but it also led to assertions that '[a]fter carefully considering the case the Independent [SPA] decided not to prosecute' (in a case where a soldier was reported for murder of a civilian) without further reasoning. ${ }^{46}$ The same phrasing appears when soldiers were referred to the SPA for the war crime of outrages upon personal dignity, for cutting off the fingers of enemy fighters killed in action, purportedly for forensic examination. ${ }^{47}$ In some cases involving sexual offences against minors, the charges brought mentioned neither that the victims were children, nor that sexual offences were at issue. ${ }^{48}$ This unusually frank release (in a sea of investigatory documents which rarely link alleged facts to subsequent investigatory or prosecutorial decisions) suggests that further scrutiny is called for, instead of a presumption against prosecution.

In the handful of cases where charges were actually brought, the vast majority were discontinued, only a tiny few were actually convicted. In the Baha Mousa case, only one corporal, Donald Payne, was convicted for ill-treating a prisoner. Many of the other soldiers involved in the incident, who were potentially guilty of crimes, were given immunity from prosecution in exchange for their cooperation with the Baha Mousa inquiry. Given the extremely low charge rate and even lower prosecution rate, a responsible executive and legislature should seek to question the sufficiency of the investigations to date, in light of the UK's international law obligations, instead of introducing a statutory presumption against prosecution.

\section{Q9. Do you agree that the measure should apply regardless of how long ago the relevant events occurred?}

No.

\section{Q10. Please provide further explanatory comments, as necessary.}

While the gathering of evidence etc. long after events have occurred places a number of practical constraints on historical investigations, the existence of practical difficulties should not serve as a justification for precluding any kind of investigation at all. Nor do such practical difficulties remove the UK's obligations to investigate and/or to prosecute or extradite where there are alleged violations of international human rights law, grave breaches of international humanitarian law, or alleged war crimes in international criminal law. Instead, States should attempt to gather the information that they can in the particular circumstances; and to fulfil their international legal obligations without introducing domestic legislation that might thwart these obligations.

\footnotetext{
$44 \quad$ Letter $\quad$ dated $\quad 2 \quad$ August $2017 \quad$ available at <https://assets.publishing.service.gov.uk/government/uploads/system/uploads/attachment_data/file/638811 /2017-06443.pdf> accessed 26 September 2019.

${ }^{45}$ Investigations into allegations of UK Forces Mistreatment of Afghan Nationals (2014) released in response to an unattributed FOI request in 2014.

${ }^{46} \mathrm{lbid}, \mathrm{FOI}$ Serial No 3, incident of 18 June 2010.

47 Ibid, FOI Serial No 8, incident of 21 March 2011.

48 ibid, FOI Serial No 21, incident of 12 December 2011.
} 
The European Court of Human Rights has ruled that the obligation to investigate violations of Articles 2 and 3 ECHR remain long after the facts. The obligations to investigate are considered separate and autonomous. ${ }^{49}$ This means that in certain circumstances the UK may be obliged to investigate acts that were committed before the UK ratified the ECHR and even before the Convention existed. ${ }^{50}$ The Court has limited this obligation so it only applies where 'a significant proportion of the procedural steps [...] have been or ought to have been carried out after the critical date [the date the ECHR enters into force in state]'. ${ }^{51}$ The UK cannot therefore pass legislation that would prevent the investigation or reinvestigation of acts and omissions alleged to have breached Articles 2 or 3 ECHR.

\title{
Q11. Do you agree with our proposal that the presumption should apply to all offences?
}

No, we very strongly disagree with this view and believe it would violate several of the UK's international legal obligations.

\section{Grave breaches of the Geneva Conventions and Additional Protocol I and War Crimes}

As the proposed legislation covers "all offences" it would include what are commonly referred to as grave breaches of the Geneva Conventions as well as war crimes. Grave breaches are defined in the Geneva Conventions

\begin{abstract}
Grave breaches [...] shall be those involving any of the following acts, if committed against persons or property protected by the Convention: wilful killing, torture or inhuman treatment, including biological experiments, wilfully causing great suffering or serious injury to body or health, and extensive destruction and appropriation of property, not justified by military necessity and carried out unlawfully and wantonly. ${ }^{52}$
\end{abstract}

Each Convention contains a set of acts that qualify as grave breaches..$^{53}$ Additional Protocol I specifies further acts that are deemed to be grave breaches. ${ }^{54}$ The Geneva Conventions and Additional Protocol I, to which the UK is a contracting party, require contracting States to search for persons alleged to have committed grave breaches and to try or extradite them to the relevant jurisdiction. ${ }^{55}$ The obligation to prosecute or extradite those suspected of involvement in grave breaches of the Four

\footnotetext{
49 Šilih v Slovenia (App No 71463/01) 9 April 2009 at [159].

${ }^{50}$ See for example Mocanu and Others $v$ Romania (App Nos 10865/09, 45886/07 and 32431/08) 13 November 2012; Paçacı and Others v Turkey (App No. 3064/07) 8 November 2011 at [64]-[66]; Janowiec and Others v Russia (App Nos 55508/07 and 29520/09) 21 October 2013 at [132].

51 Šilih (n 49) at [163]. See also clarification of the Šilih criteria in Janowiec (n 50) at [140]-[151].

52 First Geneva Convention 1949, art 50.

53 First Geneva Convention 1949, art 50; Second Geneva Convention 1949, art 51; Third Geneva Convention 1949, art 130; Fourth Geneva Convention 1949, art 147.

${ }^{54} \mathrm{API}$, arts 11 and 85.

55 First Geneva Convention 1949, art 49; Second Geneva Convention 1949, art 50; Third Geneva Convention 1949, art 129; Fourth Geneva Convention 1949, art 146. It should be noted that grave breaches only cover acts committed in an international armed conflict. There is no similar treaty obligation in non-international armed conflicts.
} 
Geneva Conventions and Additional Protocol I does not expressly endure without limitation, but there is considerable State practice of prosecutions for grave breaches decades after the relevant acts occurred. While the proposed legislation is not strictly speaking a statute of limitations, it will function in a very similar way.

States are moreover under a customary duty to investigate war crimes. ${ }^{56}$ This obligation covers not only a wider range of acts than the narrower concept of grave breaches, ${ }^{57}$ but also conduct in an international or non-international armed conflict. ${ }^{58}$ While the proposed legislation is not strictly speaking a statute of limitations, it will function in a very similar way and this would contravene Rule 160 of the ICRC Study on Customary International Humanitarian Law that unambiguously states that '[s]tatutes of limitation may not apply to war crimes. ${ }^{59}$ This view is reinforced by the fact that the prohibition of war crimes is jus cogens $s^{60}$ and thus the UK cannot use either international or national law to escape its legal obligation to investigate war crimes and punish those who have committed such crimes.

The broader trend in international law has been to ensure that domestic prescription rules do not apply to these offences. Such legal instruments include the UN Convention on the Non-Applicability of Statutory Limitations to War Crimes and Crimes against Humanity $1968^{61}$ and the European Convention on the Non-Applicability of Statutory Limitation to Crimes against Humanity and War Crimes $1974 .{ }^{62}$ Admittedly, the UK has neither signed nor ratified the UN Convention on the NonApplicability of Statute Limitations to War Crimes and Crimes Against Humanity. However, this does not mean that UK is not bound by the rule. The ICRC has indicated that the rule that statutes of limitation may not apply to war crimes is supported by extensive State practice and opinio juris (a belief among States that this is a legal obligation) and as such amounts to a rule of customary international law, which the UK is bound to uphold during international and non-international armed conflicts. ${ }^{63}$ The UK is cited by the ICRC as supporting this rule. ${ }^{64}$

\section{Rome Statute of the International Criminal Court}

56 'Rule 158. Prosecution of War Crimes' available at <https://ihl-databases.icrc.org/customary$\mathrm{ihl} / \mathrm{eng} /$ docs/v1_rul_rule158\#targetText=Rule\%20158.,if\%20appropriate\%2C\%20prosecute\%20the\%20suspect s.> accessed 26 September 2019.

${ }^{57}$ Every grave breach is a war crime but not every war crime is a grave breach.

58 See for examples the statutes of international criminal tribunals such as the International Criminal Tribunal for the Former Yugoslavia (ICTY), the International Criminal Tribunal for Rwanda (ICTR), the Special Court for Sierra Leone (SCSL) and the International Criminal Court (ICC).

59 'Rule 160. Statutes of Limitation' available at <https://ihl-databases.icrc.org/customaryihl/eng/docs/v1_rul_rule160> accessed 26 September 2019.

${ }^{60}$ See e.g. Prosecutor v Kupreškić et al, IT-95-16-T, Judgment, ICTY Tr Ch (14 January 2000) at [520]. See also discussion in International Law Commission, Fourth Report on Peremptory Norms of General International Law (jus cogens) by Dire Tladi, Special Rapporteur, UN Doc A/CN.4/727, 31 January 2019 at [116]-[121].

${ }^{61}$ Convention on the Non-Applicability of Statutory Limitations to War Crimes and Crimes Against Humanity, 754 UNTS 73 (entered into force 11 November 1970).

62 European Convention on the Non-Applicability of Statutory Limitation to Crimes against Humanity and War Crimes, ETS No 082 (entered into force 27 June 2003).

63 'Rule 160. Statutes of Limitation' available at <https://ihl-databases.icrc.org/customaryihl/eng/docs/v1_rul_rule160> accessed 26 September 2019.

64 'Practice Relating to Rule 160. Statutes of Limitation' available at <https://ihl-databases.icrc.org/customaryihl/eng/docs/v2_rul_rule160> accessed 26 September 2019. 
The UK also has obligations to criminalise genocide, war crimes and crimes against humanity under international law arising from different sources. The UK has signed and ratified the Rome Statute of the ICC. This treaty indirectly obliges the UK to criminalise genocide, war crimes and crimes against humanity in its domestic legislation, which the UK has done through s.51 of the International Criminal Court Act 2001. It is also worth noting that the crimes within the jurisdiction of the Court must not be subject to any statute of limitations. ${ }^{65}$

As the government's proposals would apply to all offences, including the international crimes specified in the Rome Statute, the application of the presumption against prosecution and investigation could indicate that the UK was unwilling to investigate or prosecute these offences. In fact, the proposals would add weight to any argument that the UK is 'unwilling ... genuinely to carry out the investigation or prosecution' under Article 17(1)(a) of the Rome Statute. Article 17(2) of the Rome Statute lists three scenarios to assist the Court in determining such unwillingness. Paragraph 2 expressly mentions a 'national decision [which] was made for the purpose of shielding' multiple potential defendants 'from criminal responsibility' for war crimes. Although there is currently no case-law on this specific provision, ${ }^{66}$ it is possible to argue that the enactment of the proposals could be interpreted as a conscious attempt to shield members of the armed forces from investigation for unlawful acts which the ICC OTP found a 'reasonable basis to believe' had been committed against detainees held by the British armed forces in Iraq. ${ }^{67}$ The Ministry of Defence's proposals might encourage the OTP to request a full investigation instead of the current preliminary examination. If this request was granted by the Pre-Trial Chamber, it would trigger the jurisdiction of the ICC meaning that ex-service personnel could be prosecuted by the ICC instead of being prosecuted domestically. In essence, far from providing peace of mind to ex-service personnel, the application of these proposals (combined with existing deficiencies in domestic investigations) could lead to them being brought before the ICC in The Hague and tried as war criminals or for crimes listed under the Statute.

\section{Torture}

If service personnel were alleged to have committed acts of torture during a military operation overseas, they would not be able to avoid prosecution through the proposed legislation. First, the prohibition of torture is a peremptory norm of international law, ${ }^{68}$ which means that the UK cannot

\footnotetext{
${ }^{65}$ Rome Statute of the ICC, art 29.

${ }^{66}$ See Klamberg, 'Article 17(2)(a)' available at < https://www.casematrixnetwork.org/cmn-knowledge-hub/icccommentary-clicc/commentary-rome-statute/commentary-rome-statute-part-2-articles-11-21/> accessed 26 September 2019.

67 ICC - Office of the Prosecutor (n 19) at [195].

68 See Prosecutor v Furundzija, Judgement, IT-95-17/1-T, ICTY Tr Ch (10 December 1998) at [151]-[157]; Prosecutor v Delalić et al, Judgment, IT-96-21-T, ICTY Tr Ch (16 November 1998) at [454]; Questions Relating to the Obligation to Prosecute or Extradite (Belgium v Senegal), Judgment, [2012] ICJ Rep 422, 20 July 2012 at [99]; Commentary to Article 26 of Draft Articles on Responsibility of States for Internationally Wrongful Acts with Commentaries (Report of the International Law Commission on the work of its fifty-third session (23 April-1 June and 2 July-10 August 2001), UN Doc A/56/10, at 85; Report of the Study Group of the International Law Commission on the Fragmentation of International Law: Difficulties Arising from the Diversification and Expansion of International Law, UN Doc A/CN.4/L.682, 13 April 2006, [374]; International Law Commission, Fourth Report on Peremptory Norms of General International Law (jus cogens) by Dire Tladi, Special Rapporteur, UN Doc A/CN.4/727, 31 January 2019 at [69]-[77].
} 
set it aside by invoking other international legal norms. ${ }^{69}$ Also, as the ICTY explained in Furundzija, a consequence of the jus cogens character of the prohibition of torture is that in spite of possible national authorisation by legislative or judicial bodies to violate the principle banning torture, individuals remain bound to comply with that principle. ${ }^{70}$ The prohibition would continue to apply regardless of any domestic measures the State adopted. Another consequence of the jus cogens nature of the prohibition of torture is 'that every State is entitled to investigate, prosecute and punish or extradite individuals accused of torture, who are present in a territory under its jurisdiction.${ }^{71} \mathrm{~A}$ similar obligation arises under the CAT, which the UK has also ratified. This treaty creates a temporally unlimited obligation to try or extradite persons within its territory alleged to have committed offences contrary to that treaty. ${ }^{72}$ This would include where service personnel are alleged to have committed acts of torture, attempted torture, participation in torture or complicity in torture. ${ }^{73}$ If the objective of the legislation is to give service personnel peace of mind that they will not be prosecuted after a set period of time, this would be impossible if they were alleged to have committed acts of torture or other international crimes. ${ }^{74}$ This is because such offences can trigger universal jurisdiction under international law. ${ }^{75}$ Universal jurisdiction grants all States the right to prosecute persons suspected of committing certain offences, such as torture, regardless of where the crime has occurred or the nationality of the accused person or victim. Thus, if the service personnel suspected of such crimes ever left the UK's jurisdiction, they would be at risk of arrest and prosecution in any other jurisdiction.

It is also worth noting that several international bodies consider that time bars, amnesties and other impediments which limit criminal proceedings related to torture or ill-treatment are incompatible with international law. No statute of limitations can apply to the crime of torture. ${ }^{76}$ The United Nations Committee against Torture oversees the implementation of the CAT. It has stated

The Committee considers that amnesties or other impediments which preclude or indicate unwillingness to provide prompt and fair prosecution and punishment of perpetrators of torture or ill-treatment violate the principle of non-derogability. ${ }^{77}$

The European Court of Human Rights has ruled that time bars, amnesties and pardons for criminal proceedings related to torture or ill-treatment are incompatible with the ECHR. In the case of Abdulsamet Yaman $v$ Turkey the Court stated

where a State agent has been charged with crimes involving torture or ill-treatment, it is of the utmost importance for the purposes of an "effective remedy" that criminal proceedings and

\footnotetext{
${ }^{69}$ Vienna Convention on the Law of Treaties, arts 53, 64.

${ }^{70}$ Furundzija (n 68) at [155].

${ }^{71}$ Furundzija (n 68) at [156].

72 CAT, art 7(1). See also Questions Relating to the Obligation to Prosecute or Extradite (Belgium v Senegal) (n $68)$ at [114]-[117].

${ }^{73}$ CAT, art 4.

${ }^{74}$ Prosecutor v Tadic, Decision on the Defence Motion of Interlocutory Appeal on Jurisdiction, IT-94-1, ICTY App Ch (2 Oct 1995) at [62].

${ }^{75}$ CAT, art 5.

${ }^{76}$ Furundzija (n 68) at [157].

77 UN Committee Against Torture, General Comment No. 2: Implementation of Article 2 by States Parties, UN Doc CAT/C/GC/2, 24 January 2008 available at <https://www.refworld.org/docid/47ac78ce2.html> accessed 29 September 2019 at [5].
} 
sentencing are not time-barred and that the granting of an amnesty or pardon should not be permissible. $^{78}$

The Court also observed in a separate case that national authorities should not give the impression that they are willing to allow crimes involving torture or ill-treatment to go unpunished. ${ }^{79}$ The State has an obligation not just to investigate allegations of such crimes, but also to prosecute the perpetrators. ${ }^{80}$ It is not possible for the UK to derogate from this Article of the ECHR. ${ }^{81}$

\section{Other Obligations in International Law}

The adoption of the legislation itself may be a violation of the UK's "framework" obligations under the ECHR. Firstly, it is worth noting that even though the actions covered by the legislation will occur "outside the UK" that does not mean that they will occur "outside the jurisdiction" of the UK for the purposes of human rights law. The European Court of Human Rights has explained that the Convention is applicable in an extra-territorial context when the State is exercising de facto authority or effective control. ${ }^{82}$ This jurisdiction can arise in several different ways, the most common of which is 'State agent authority' or 'personal jurisdiction'. This is most relevant to the issue at hand because the actions or omissions of State agents can generate jurisdictional links to the State and an obligation on the part of the individual soldier to comply with human rights law. In the context of the armed forces, the European Commission on Human Rights observed

armed forces are authorised agents of Turkey and [...] they bring any other persons or property in Cyprus 'within the jurisdiction' of Turkey, in the sense of Article 1 of the Convention, to the extent that they exercise control over such persons or property. Therefore, in so far as these armed forces, by their acts or omissions, affect such persons' rights or freedoms under the Convention, the responsibility of Turkey is engaged. ${ }^{83}$

The second main model of extra-territorial jurisdiction is commonly referred to as spatial jurisdiction or jurisdiction arising from effective control over an area. ${ }^{84}$ This can arise where a State is in de facto control of territory outside its national territory. As the European Court observed in Loizidou $v$ Turkey

the responsibility of a Contracting Party may also arise when as a consequence of military action - whether lawful or unlawful-it exercises effective control of an area outside its national territory. The obligation to secure, in such an area, the rights and freedoms set out in the Convention, derives from the fact of such control whether it be exercised directly, through its armed forces, or through a subordinate local administration. ${ }^{85}$

\footnotetext{
${ }^{78}$ Abdulsamet Yaman v Turkey (App No 32446/96) 2 November 2004 at [55].

${ }^{79}$ Egmez v Cyprus (App No 30873/96) 21 December 2000 at [71].

${ }^{80}$ Gäfgen v Germany (App No 22978/05) 1 June 2010 at [119].

${ }^{81} \mathrm{ECHR}$, art 15(2).

82 Wallace (n 27) at 43-72; Written Evidence from Quénivet and Sari (DRO0010) submitted to the Joint Committee on Human Rights in 2015, available at <http://data.parliament.uk/writtenevidence/committeeevidence.svc/evidencedocument/human-rightscommittee/the-uk-governments-policy-on-the-use-of-drones-for-targeted-killing/written/24475.html> accessed 26 September 2019 at [20]. See also discussion at [21]-[23].

83 Cyprus v Turkey (1975) 31 DR 125, 137.

${ }^{84}$ See, for example, Milanovic, 'Al-Skeini and Al-Jedda in Strasbourg' (2012) 23 European Journal of International Law 121, 122; Raible, 'The Extraterritoriality of the ECHR: Why Jaloud and Pisari Should be Read as Game Changers' [2016] European Human Rights Law Review 161, 163.

${ }^{85}$ Loizidou v Turkey (Preliminary Objections) (App No 15318/89) 23 March 1995 at [62].
} 
Thus, if jurisdiction is established according to such criteria and the ECHR applies, the UK could be held responsible for violations of Articles 2 and 3 if British service personnel were to use force unlawfully against an individual or ill-treat an individual. The UK is therefore under a duty to investigate such conduct, an obligation of means and not results. ${ }^{86}$ This does not mean that the service personnel must be prosecuted, but if their actions appear to be unlawful, they must be investigated. ${ }^{87}$

With regard to Article 2, the obligation requires that the investigation be capable of determining whether a use of force was justified in the circumstances, identifying and, if necessary, punishing those responsible. ${ }^{88}$ The very adoption of the legislation restricting prosecution and further investigation may contravene the UK's framework obligations under the ECHR, which require the UK to adopt an appropriate regulatory framework to safeguard the lives of those within its jurisdiction and that such a framework contain both substantive and procedural aspects. As the European Court observed in Keenan $v$ United Kingdom

the first sentence of Article $2 \S 1$ enjoins the State not only to refrain from the intentional and unlawful taking of life, but also to take appropriate steps to safeguard the lives of those within its jurisdiction [...]. This involves a primary duty on the State to secure the right to life by putting in place effective criminal-law provisions to deter the commission of offences against the person backed up by law-enforcement machinery for the prevention, suppression and punishment of breaches of such provisions. ${ }^{89}$

In the context of Article 3, for example, the prohibition on torture, inhuman and degrading treatment or punishment, the European Court of Human Rights has stated

The obligation imposed on High Contracting Parties under Article 1 of the Convention to secure to everyone within their jurisdiction the rights and freedoms defined in the Convention, taken together with Article 3, requires States to take measures designed to ensure that individuals within their jurisdiction are not subjected to torture or inhuman or degrading treatment [...] State responsibility may therefore be engaged where the framework of law fails to provide adequate protection. ${ }^{90}$

It seems self-evident that a presumption against prosecution and further investigation where a violation of the right to life or prohibition on torture, inhuman and degrading treatment or punishment is suspected would violate these framework obligations.

\section{Q12. Are there any offences which you think should be excluded from the measure?}

At a minimum the proposals must exclude:

\footnotetext{
${ }^{86}$ Al-Skeini (n 21) at [166]. See also Isayeva v Russia (App No 57950/00) 24 February 2005 at [211]; Estamirov and Others $v$ Russia (App No 60272/00) 12 January 2007 at [86].

${ }^{87}$ For a discussion on the threshold that triggers the duty to investigate, see Quénivet (n 28) at 123-125; Wallace (n 27) at 111-115.

${ }^{88}$ Oğur v Turkey (App No 21594/93) 20 May 1999 at [88]; Al-Skeini (n 21) at [166]; Jaloud (n 32) at [200].

${ }^{89}$ Keenan v UK (App No 27229/95) 3 March 2001 at [89].

${ }^{90}$ Mahmut Kaya v Turkey (App No 22535/93) 28 March 2000 at [115].
} 
- Grave breaches of the Geneva Conventions and Additional Protocol I;

- War crimes (including, but not limited to, wilful killing/murder, torture and inhuman/cruel treatment, outrages upon personal dignity; rape and other forms of sexual violence);

- Crimes against humanity;

- Genocide;

- Violations of the right to life that are inconsistent with international human rights law;

- Offences related to the prohibition on torture, including inchoate offences.

\section{Q13. Please tell us why you think this.}

[see answer to $Q .11$ above]

\section{Q14. Do you support the option of only allowing the presumption to be overridden where a prosecutor considers that there are 'exceptional circumstances' in a particular case (Option 1), or the option of allowing a prosecutor to bring a prosecution notwithstanding the presumption wherever they consider it in the public interest to do so, having regard to all the circumstances of the case including (but not limited to) certain factors specified in legislation (Option 2)?}

Neither.

\section{Q15. Please tell us why you think this.}

We cannot support Option 1 or Option 2. However, as explained above [answer to Q.2], the quality of the initial investigation (judged in terms of the UK's obligations under international human rights law, international humanitarian law and international criminal law) is extremely important. The proposals assume (without providing evidence) that all of the investigations into historic allegations to date have been lawful and complete. There might be many reasons in an individual case, or in groups of cases, why these investigations should be re-examined (each of which might amount to an 'exceptional circumstance' justifying the re-opening of an investigation or the beginning of a prosecution). The information released is insufficient for any meaningful public scrutiny of the quality of these investigations; so already, they fail the public scrutiny criterion under Articles 2 and 3 of the ECHR. We would not support confining the definition of 'exceptional circumstances' to the emergence of new evidence alone. It must also include deficits in the original investigation, defined in terms of domestic or international law. Option 2 would offer only a narrow, discretionary safeguard against the violation of the UK's international law obligations to investigate a number of crimes under international humanitarian law, international human rights law and international criminal law. Relying solely on a 'public interest' determination by the SPA has risks, not least because the public interest specifically in the prosecution of war crimes or crimes against humanity (as recognised by the European Court of 
Human Rights in Brecknell) $)^{91}$ and in the prosecution of other acts prohibited by international law is not made explicit in the CPS Full Code Test. ${ }^{92}$ Instead 'public interest' determinations enable the weighing of multiple considerations, including 'proportionality' and resources, and defendant-focused considerations, which are deracinated from international law.

Q16. If we proceed with the second option set out above, are there any other specific factors to which you think a prosecutor should be required to have regard in determining whether to override the presumption and bring a prosecution, beyond those listed above?

Yes, there is a public interest in the prosecution of war crimes, as noted by the European Court of Human Rights in Brecknell $v$ UK. This should take precedence over the other criteria for the public interest as defined in the CPS Code Full Test (applied by the SPA).

\section{Q17. Please provide further explanatory comments, as necessary.} No comment.

\section{Q18. Please give us your views on this}

No comment.

\section{Q19. Do you support enacting this measure?}

No.

\section{Q20. Please tell us why you think this.}

Firstly, as noted above, very few prosecutions are actually brought in practice against service personnel for murder. We fail to see how this is a pressing concern for criminal law reform when other areas of the criminal law are in dire need of reform.

Secondly, the UK already has a broad public/private defence [self-defence] law, which takes into account a number of subjective criteria of the defendant and offers the jury a large degree of discretion in evaluating the proportionality of the force used in response to a threat.

Thirdly, in the circumstances described i.e. 'the unique pressures' of active combat operations, a partial defence is already available. Where excessive force is used, precluding reliance on the

\footnotetext{
${ }^{91}$ Brecknell v UK (App No 32457/04) 27 February 2008 at [69].

92 The Code for Crown Prosecutors (2018) available at <https://www.cps.gov.uk/publication/code-crownprosecutors > accessed 26 September 2019.
} 
public/private defence, but that force was used because of peculiar mental characteristics of the defendant, such as mental illness, defendants have been able to rely on the partial defence of diminished responsibility. ${ }^{93}$ Under s.52 of the Coroners and Justice Act 2009, if the defendant can prove he was suffering from an abnormality of mental functioning caused by a recognised medical condition and that it substantially impaired his ability to (a) understand the nature of his conduct; (b) form a rational judgment; or (c) exercise self-control and these factors explain the defendant's act or omission, they have a partial defence to a murder charge and the charge is reduced from murder to manslaughter.

The paradigmatic example here is the case of Sgt. Alexander Blackman. Blackman was convicted of murder by a court-martial in 2013 after shooting an injured insurgent while deployed in Afghanistan. On appeal, Sgt. Blackman raised the partial defence of diminished responsibility on the grounds that he was suffering from an 'adjustment disorder' brought on by the 'exceptional stressors' he faced during the military operation. As a result, the Court of Appeal quashed his murder conviction and substituted it with a conviction for manslaughter by reason of diminished responsibility. ${ }^{94}$

Q21. Please give us your views on whether the measure should apply across the UK.

No comment.

\section{Q22. Are there any other legal protections measures for Armed Forces personnel and veterans, in this context, which you think the Ministry of Defence should be considering?}

No.

\section{Q23. If yes, please provide details.}

\footnotetext{
${ }^{93} R$ v Martin (Anthony Edward) [2001] EWCA Crim 2245.

${ }^{94} R$ v Blackman [2017] EWCA Crim 190.
} 


\section{Conclusion}

The proposed measures will not remove the uncertainty ex-service personnel face regarding investigations and potential prosecutions for alleged historical crimes during extra-territorial military operations. The UK's continued obligations under various treaties make this impossible. Where exservice personnel are suspected of having committed international crimes, far from providing peace of mind, these proposals could lead to ex-service personnel being tried before the ICC or in other jurisdictions. They would not be able to leave the UK's jurisdiction without fear of arrest and prosecution. The proposed measures, analogous as they are to time bars, amnesties and other impediments which limit criminal proceedings for historical crimes, would be incompatible with international law. It will not be possible for the UK to derogate from these international legal obligations to avoid these consequences.

It also seems counter-intuitive to leave open the possibility of re-investigating any crime that has occurred in the UK, even where it has been investigated with all of the resources at the disposal of the State, but to introduce a presumption against re-investigation of these historical cases, which will typically be carried out under much more difficult circumstances and with much fewer resources.

The proposed measures are also unduly restrictive of the circumstances in which investigations can be re-opened by the State and the UK's track record in investigating alleged wrongdoing during extraterritorial military operations is poor. The combination of these two factors is a serious cause for concern and may incentivise poor investigations in the future, followed by reliance on the presumptions proposed.

The proposal to create a new partial defence exclusively for service personnel seems unnecessary given that existing defences under UK criminal law are broad enough to accommodate the circumstances described in the justification for this new partial defence. 